\title{
ENDOTHELIUM -DEPENDENT RELAXATION OF INTERNAL MAMMARY ARTERY PRODUCED BY RESVERATROL
}

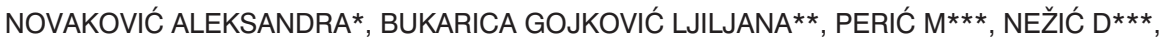 \\ ĐUKANOVIĆ $\mathrm{B}^{\star * *}$, LEŠIĆ $\mathrm{A}^{\star * *}$, BUMBAŠIREVIĆ $\mathrm{M}^{\star * \star *}$, and MARKOVIĆ-LIPKOVSKI JASMINA* \\ *School of Pharmacy, Belgrade; **School of Medicine, Belgrade; \\ ***Institute of Cardiovascular Diseases "Dedinje", Belgrade; \\ $\star * * \star$ Institute of Orthopedics and Traumatology, Clinical Center of Serbia, Belgrade
}

(Received 6. September 2005)

Resveratrol, a polyphenol present in wine, has been thought to be responsible for cardiovascular benefits associated with moderate wine consuption. It is also present in the plant Polygonum Cuspidatum. The mechanism of cardiovascular benefits probably includes vasorelaxation, antioxidant and anti-platelet effects of resveratrol. The mechanisms by which resveratrol causes vasodilatation are uncertain. The aim of this study was to investigate the mechanism(s) of resveratrolinduced vasorelaxation in human internal mammary artery (HIMA) with endothelium. HIMA rings were precontracted by phenylephrine. Resveratrol induced relaxation of the HIMA rings with endothelium. LNAME, an inhibitor of NO synthase, and methylene blue, an inhibitor of guanylate cyclase, abolished relaxation of HIMA, induced by resveratrol. Highly selective blocker of ATP-sensitive $K^{+}$channels, glibenclamide as well as a nonselective blocker of big Ca-sensitive $\mathrm{K}^{+}$ channels, charybdotoxin did not block resveratrol-induced relaxation of HIMA. 4-Aminopyridine and margatoxin, blockers of voltage-gated $K^{+}$ $\left(K_{V}\right)$ channels, abolished endothelium-dependent relaxation of HIMA, induced by resveratrol. In conclusion, we have shown that resveratrol induces relaxation of HIMA with endothelium. It seems that NO and smooth muscle $K_{V}$ channels are included in this relaxation.

Key words: mammary artery, $\mathrm{K}^{+}$channel, NO, resveratrol, vasorelaxation

\section{INTRODUCTION}

Epidemiological studies have suggested that dietary factors, including moderate wine consumption, might reduce the risk of cardiovascular diseases (Diebolt et al., 2001). The lower incidence of coronary artery disease in Soutern French and other Mediterranean populations, despite a diet rich in saturated fat and high smoking habits (the so-called French paradox), has been attributed to prolonged and moderate red wine consumption by these populations (Orallo et 
al., 2002). It is considered that resveratrol, as a polyphenol, is present in red wine in significant amounts, and is partly responsible for the cardiovascular benefits associated with wine consumption. The mechanism of cardiovascular benefits probably includes vasorelaxation, antioxidant and anti-platelet effects of resveratrol (Wu et al., 2001).

The mechanisms by which resveratrol causes vasodilatation are uncertain. Today is known, that resveratrol-induced vasorelaxation may either be endothelium-dependent (attenuated by L-NAME) or endothelium-independent (Naderali et al., 2001). Resveratrol might become incorporated into the smooth muscle membrane, where it could either couple with a membrane receptor or interact directly with membrane ion channels, thus inducing endothelium independent vasorelaxation (Jager and Nguyen-Duong, 1999; Andriambeloson et al., 1999). Recently, it has been shown that some endothelial and peripherial effects of resveratrol are mediated by activation of $\mathrm{Ca}^{2+}$ activated and voltagegated $\mathrm{K}^{+}\left(\mathrm{K}_{\mathrm{v}}\right)$ channels (Wu, 2003, Granados-Soto et al., 2002).

HIMA is the vessel of choice for coronary artery bypass grafting (CABG). Spasm of arterial graft conduit may occur during harvesting or immediately following CABG (Rosenfeldt et al., 1999). The mechanism of graft spasm is not yet elucidated although physical (mechanical manipulation, temperature changes), and humoral factors (circulating vasoconstricting substances) have been evoked (He et al., 1995). We have shown that potassium channel openers, pinacidil, levcromakalim and rilmakalim, are potent antivasoconstrictors and vasodilatating agents on the HIMA and that they can be considered as potential drugs in the prevention of the bypass graft spasm (Gojkovic Bukarica et al., 1997, Novakovic et al., 2003). Resveratrol is present in the plant Polygonum Cuspidatum. Its effects on coronary bypass grafts have not been studied yet. Since some authors (Andriambeloson et al., 1999; Chen et al., 1996; Naderali et al., 2000) have studied the effects of resveratrol in animals, the authors performed the study on human arteries, which are important both in cardiac and orthopedic surgery. Therefore, the aim of this study was to investigate the effect of resveratrol on HIMA, with endothelium, used as coronary bypass grafts, and to define the contribution of different $\mathrm{K}^{+}$channel subtypes in resveratrol action on this blood vessel.

\section{MATERIAL AND METHODS}

The HIMA $(n=49)$ segments were collected from male patients $(n=49)$ undergoing CABG suffering from coronary artery disease. Only arteries without macroscopic evidence of atherosclerosis were used. All patients gave their formal consent for excision of the remaining tissue. The experimental protocol was approved by The Ethical Committee of Institute for cardiovascular diseases "Dedinje". Research has been carried out in the accordance with Declaration of Helsinki (2000) of the World Medical Association. The vessels were excised within $10 \mathrm{~min}$ of clamping the blood flow and placed in cold $\left(4^{\circ} \mathrm{C}\right)$ Krebs-Ringerbicarbonate solution. After excision, the vessels were immediately transported to the laboratory. 


\section{Assessment of vascular function}

The HIMA segments were dissected free from connective tissue. They were cut into rings $(3 \mathrm{~mm})$ and were mounted between two stainless-steel triangles in an organ bath containing $10 \mathrm{ml}$ Krebs-Ringer-bicarbonate solution $\left(37^{\circ} \mathrm{C}, \mathrm{pH}\right.$ of 7.4), aerated with $95 \% \mathrm{O}_{2}$ and $5 \% \mathrm{CO}_{2}$. One of the triangles has been attached to a displacement unit allowing fine adjustments of tension and the other was connected to an isometric transducer (K30, Hugo Sachs, Freiburg, Germany).

The preparations were allowed to equilibrate for $30 \mathrm{~min}$. During this period, the vessels have been washed with a fresh buffer solution every $10 \mathrm{~min}$. After the equilibration period, the length-tension characteristics for each vessel were determined as described previously (Gojkovic Bukarica et al., 1997). The resting tension was $2 \mathrm{~g}$ (Schoeffter et al., 1988). Vascular rings were allowed a further 30 min to equilibrate before being contracted with phenylephrine.

Concentration-response curves were obtained by the cumulative addition of resveratrol (1-100 $\mathrm{M})$ to ring segments contracted to a stable plateau by adding phenylephrine $(10 \mathrm{M})$. Increasing concentrations of resveratrol have been added only after the previous concentration had produced an equilibrium response or after $20 \mathrm{~min}$ if no response was obtained. Therefore, the following protocol was used: 1) contraction to phenylephrine and concentration-response curve to resveratrol followed by three washes, addition of different $\mathrm{K}^{+}$-channel blockers and a 20 min equilibration period; 2) contraction to phenylephrine and the concentration-response curve to resveratrol.

We have examined the effects of resveratrol onto the rings with intact endothelium. To assess the endothelial integrity of the preparation we have used acetylcholine $(20 \mathrm{M})$. Endothelium was considered to be intact when this drug produced a strong vasorelaxation $(>80 \%)$ of precontracted vascular rings. Failure of arteries to relax to acetylcholine was considered to indicate a state of endothelial denudation.

\section{Data analysis}

Relaxation produced by each concentration of resveratrol was measured and expressed as a percentage of the maximum possible relaxation (i.e., relaxation back to the baseline tension). The concentration of resveratrol producing $50 \%$ of the maximum response $\left(\mathrm{EC}_{50}\right)$ was determined graphically for each curve by linear interpolation.

The results are expressed as the means \pm standard error of the mean (SEM); $n$ refers to the number of experiments. Statistical difference between means was determined by Student's $t$-test, and a $P$ value $<0.05$ was considered statistically significant.

\section{Drugs}

The following drugs were used: trans-resveratrol, phenylephrine, acetylcholine, glibenclamide, charybdotoxin, 4-amynopiridine (4-AP), and margatoxin (Sigma Chemical Co, St Louis, MO, USA). Resveratrol was dissolved in $70 \% \mathrm{v} / \mathrm{v}$ ethanol with further dilution in distilled water before use. Working 
concentrations of ethanol in the bath were $<0.01 \%(\mathrm{v} / \mathrm{v})$. Glibenclamide was dissolved in polyethylene glycol. Previous experiments showed that the solvents used had no effects on preparations at the concentrations applied. All drugs were added directly to the bath in a volume of $50 \mathrm{~L}$ and the concentrations given were the calculated final concentrations of the bath solution.

\section{RESULTS}

\section{Effects of resveratrol on precontracted HIMA}

Figure 1 shows the effect of resveratrol on the HIMA precontracted with phenylephrine $(10 \mathrm{M})$. Resveratrol $(1-100 \mathrm{M})$ induced a concentrationdependent relaxation of HIMA rings with endothelium $\left(\mathrm{EC}_{50}\right.$ values of $34.7 \pm$ $0.11 \mathrm{M}$, maximal response $86 \pm 2 \%, \mathrm{n}=49$ ), (Fig. 1).

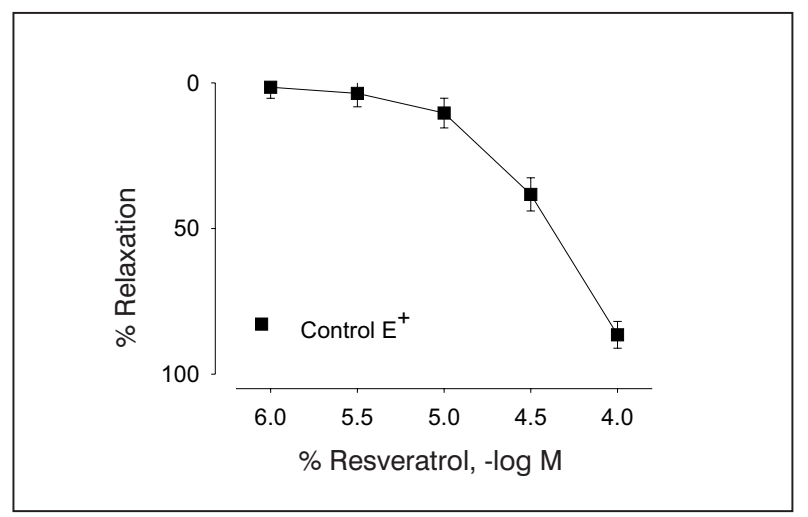

Figure 1. Concentration-response curve for resveratrol in the human internal mammary artery. Rings were precontracted with phenylephrine $\left(\begin{array}{ll}10 & M\end{array}\right)$. Responses are expressed as a percentage of the maximum possible relaxation, i.e., the return of tension to the pre-phenylephrine level. Each point represents the mean \pm SEM $(n=49)$

\section{Effects of L-NAME and methylene blue on resveratrol-induced relaxation}

L-NAME $(100 \mathrm{M})$ and methylene blue $(10 \mathrm{M})$ abolished resveratrolinduced relaxation of HIMA (maximal responses: $83 \pm 2 \%$ in the absence vs. $2 \pm$ $2 \%$ in the presence of L-NAME, $p<0.01, n=7$, and maximal responses: $83 \pm 2 \%$ in the absence vs. $16 \pm 2 \%$ in the presence of methylene blue, $p<0.011, n=7$, respectively (Figure $2 \mathrm{~A}$ and $2 \mathrm{~B}$ ). 


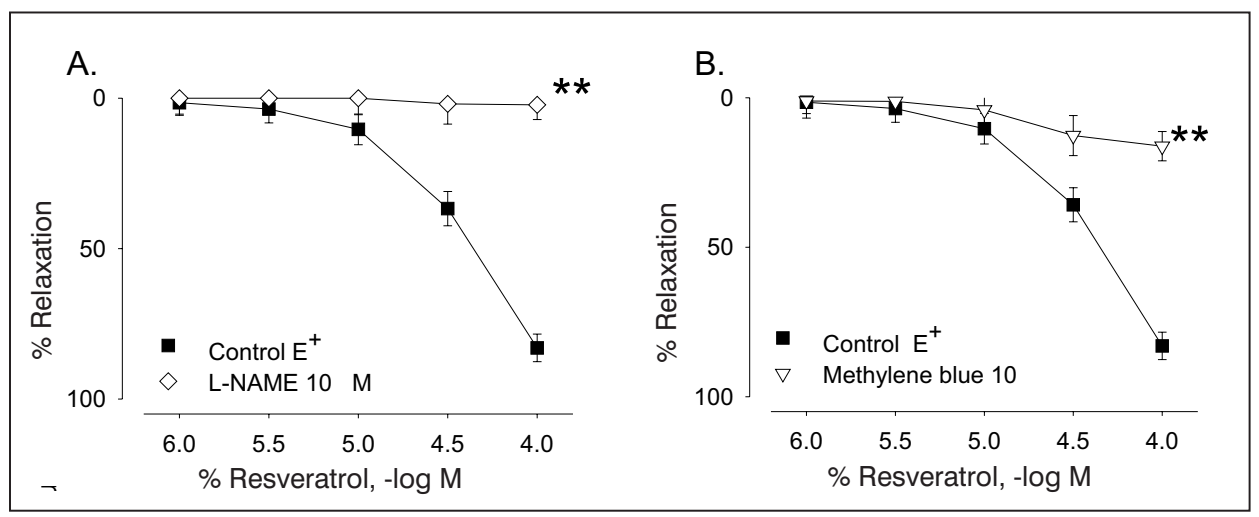

Figure 2. Antagonism of the relaxant effect of resveratrol by a L-NAME and methylene blue in the human internal mammary artery. Concentration-response curves for resveratrol in the absence and presence of L-NAME (A) and methylene blue (B). Responses are expressed as a percentage of the maximum possible relaxation, i.e., the return of tension to the pre-phenylephrine level. Each point represents the mean \pm SEM $(n=7)$. Significance of differences: ${ }^{* *} P<0.01$

\section{Effects of potassium channel antagonists on the resveratrol-induced relaxation of HIMA with endothelium}

Glibenclamide (10 M), charybdotoxin (10 nM), 4-AP (3 mM), and margatoxin (10 nM) did not affect basal tension of HIMA $(n=7$, each; data not shown).

Glibenclamide $(10 \mathrm{M})$, a selective ATP-sensitive $\mathrm{K}^{+}\left(\mathrm{K}_{\text {ATP }}\right)$ channels blocker did not significantly modify the relaxation of HIMA induced by resveratrol $\left(\mathrm{EC}_{50}=\right.$ $36.1 \pm 0.14 \mathrm{M}$ in the absence vs. $38.9 \pm 0.11 \mathrm{M}$ in the presence of glibenclamide, $P>0.05$; maximal response $86 \pm 2 \%$ in the absence vs. $83 \pm 5 \%$ in the presence of glibenclamide, $P>0.05, n=7$ ) (Fig. 3A).

Charybdotoxin $(10 \mathrm{nM})$, an inhibitor of big Ca-sensitive $\mathrm{K}^{+}\left(\mathrm{BK}_{\mathrm{Ca}}\right)$ channels as well as $\mathrm{K}_{\mathrm{V}}$ channels did not affect the relaxation of HIMA produced by resveratrol $\left(\mathrm{EC}_{50}=38.5 \pm 0.17 \mathrm{M}\right.$ in the absence vs. $43.1 \pm 0.12 \mathrm{M}$ in the presence of charybdotoxin, $\mathrm{P}>0.05$; maximal response $88 \pm 2 \%$ in the absence vs. $83 \pm 2 \%$ in the presence of charybdotoxin, $P>0.05, n=7$ ) (Fig. 3B).

4-AP $(3 \mathrm{mM})$, predominant blocker of $K_{V}$ channels abolished resveratrolinduced relaxation of HIMA (maximal response: $89 \pm 2 \%$ in the absence vs. $4 \pm$ $2 \%$ in the presence of $4-A P, P<0.01, n=7$ ) (Fig. 3C).

Margatoxin $(10 \mathrm{nM})$, potent inhibitor of $\mathrm{K}_{\mathrm{v}} 1.1, \mathrm{~K}_{\mathrm{v}} 1.2, \mathrm{~K}_{\mathrm{v}} 1.3$, and $\mathrm{K}_{\mathrm{v}} 1.6$ channels abolished the resveratrol-induced relaxation of the HIMA (maximal responses: $83 \pm 2 \%$ in the absence vs. $4 \pm 2 \%$ in the presence of margatoxin, $\mathrm{p}<0.01, \mathrm{n}=7$ ) (Fig. 3D). 


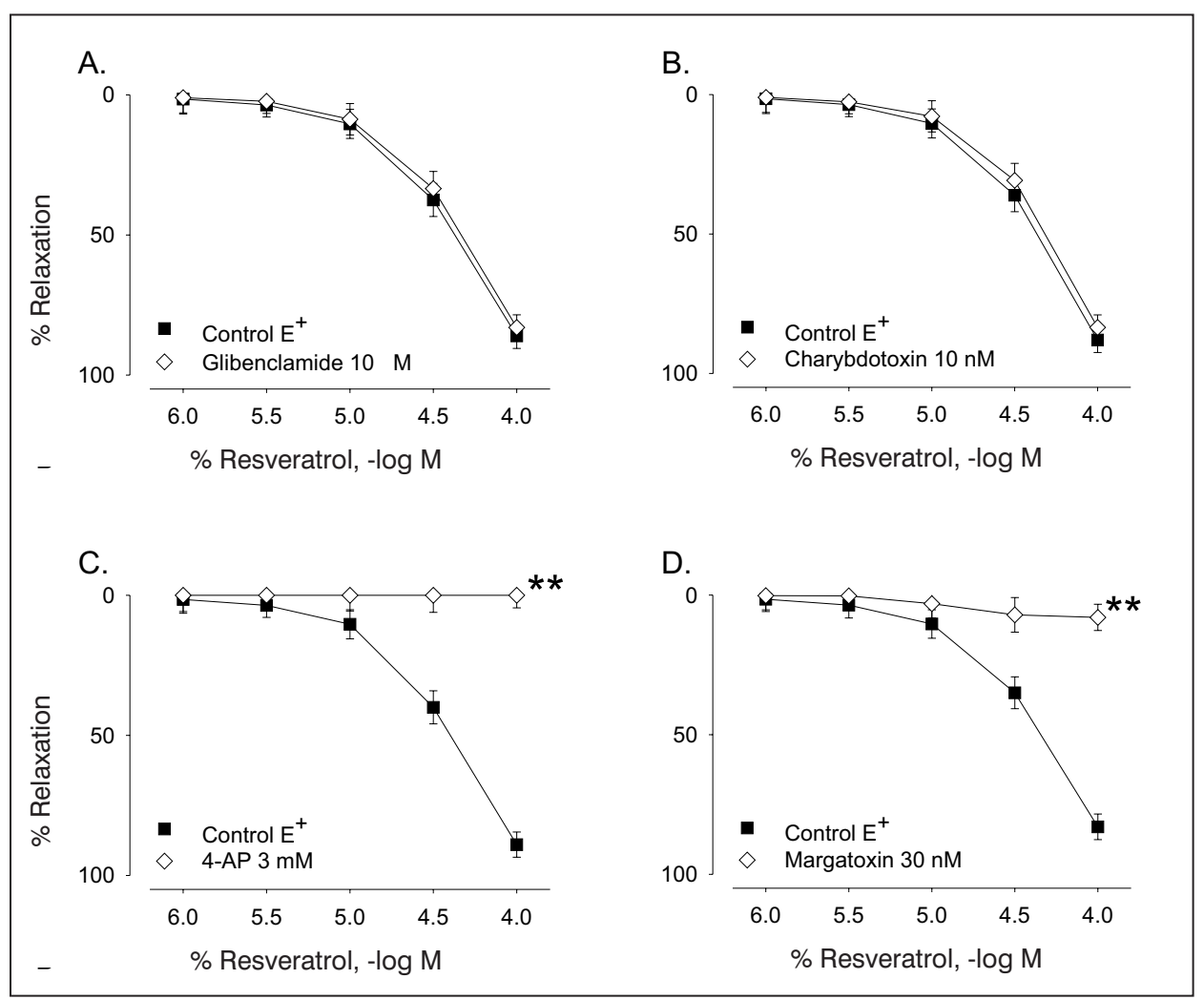

Figure 3. Antagonism of the relaxant effect of resveratrol by a $\mathrm{K}^{+}$channel inhibitors in the human internal mammary artery. Concentration-response curves for resveratrol in the absence and presence of: glibenclamide (A), charybdotoxin (B), 4-amynopiridine (C) and margatoxin (D). Arteries were contracted with phenylephrine $(10 \mathrm{M})$. Responses are expressed as a percentage of the maximum possible relaxation, i.e., the return of tension to the pre-phenylephrine level. Each point represents the mean \pm SEM $(n=7)$. Significance of differences: ${ }^{* *} P<0.01$

\section{DISCUSSION}

Several studies suggested vasorelaxant effects of polyphenolic compounds (Andriambeloson et al., 1997; Fitzpatrick et al., 1995). Resveratrol is thought to be a prime compound of the polyphenols, causing relaxation of the rat aorta, mesenteric and uterine artery of guinea pig, prior contracted by phenylephrine, noradrenaline or KCl (Chen and Pace-Asciak, 1996; Naderali et al., 2000; Orallo et al., 2001; Naderali et al., 2001). In the present study, we have shown that resveratrol induces concentration-dependent relaxation of HIMA with endothelium. 
Today it is known that the endothelium-dependent effect of resveratrol is apparent at low concentrations (10-30 $\mathrm{M})$ and is blocked by inhibitors of NO synthase. In our study, pretreatment with L-NAME, an inhibitor NO synthesis, completely abolished endothelium-dependent relaxation of HIMA rings produced by resveratrol. This finding is in agreement with previous reports where resveratrol-induced vasodilatation was attenuated by inhibitors of NO synthesis (Chen and Pace-Asciak, 1996; Fitzpatrick et al., 1995; Naderali et al., 2001). In addition, the relaxation induced by resveratrol was blocked by methylene blue, an inhibitor of soluble guanylate cyclase (Kuriyama et al., 1995, Moncada et al., 1997). These results correspond to those reported in the rat aorta by Orallo et al. (2002). According to this, it seems that endothelium-dependent vasorelaxation of HIMA caused by resveratrol could be mediated by endothelial generation and release of NO. Indeed, NO is the predominant endothelium derived dilator of the HIMA and synthesized after stimulation with vasoconstrictor phenylephrine (Archer et al., 2003). The mechanism underlying the NO-induced vasodilatation has been intensively investigated. Current knowledge suggests a central role for cGMP-dependent activation PKGI which can phosphorylate different membrane proteins. NO can also activate KCa channels and increase the outward potassium current. It has been shown that this action of $\mathrm{NO}$ can be both independent and dependent on activation PKGI (Gewalting and Kojda, 2002). Finally, cGMPdependent inhibition of voltage-gated $\mathrm{Ca}$-channels might also be involved in the mechanism of vasodilatation induced by NO. The relative contribution of each of these $\mathrm{PKGI}$ and $\mathrm{K}^{+}$channels dependent vasodilating mechanisms of $\mathrm{NO}$ remains to be determined (Gewalting and Kojda, 2002).

To determine whether the $\mathrm{K}^{+}$channels mediated relaxation of HIMA with endothelium induced by resveratrol, we used different potassium channel blockers.

To analyze the contribution of $\mathrm{K}_{\text {ATP }}$ channels to the endothelium-dependent resveratrol-induced relaxation of the HIMA, we used glibenclamide $(10 \mathrm{M})$. Glibenclamide is known as one of the most selective blockers of $\mathrm{K}_{\text {ATP }}$ channels, although when used in a high concentration ( $>30 \mathrm{M})$, it may block some other types of $\mathrm{K}^{+}$channels (Sturgess et al., 1985, Schmid-Antomarchi et al., 1987, Cook and Quast, 1990). In the present study, glibenclamide did not inhibit the relaxation of HIMA induced by resveratrol. Accordingly, it seems that $\mathrm{K}_{\text {ATP }}$ channels are not involved in the pathway by which resveratrol produces a relaxation of the HIMA. This result is in agreement with the view that glibenclamide does not antagonize antinociceptive effect of resveratrol (Granados-Soto et al., 2002).

To analyze the possibility that the endothelium-dependent relaxation of the HIMA, evoked by resveratrol, is mediated via $\mathrm{BK}_{\mathrm{Ca}}$ channels, charybdotoxin was tested. It has been shown that charybdotoxin blocks $\mathrm{BK}_{\mathrm{Ca}}$ channels in the vascular smooth muscle (Cook and Quast, 1990). However, charybdotoxin is not a specific blocker of $\mathrm{BK}_{\mathrm{Ca}}$ channels, it also inhibits intermediate conductance $\mathrm{Ca}^{2+}$-activated $\mathrm{K}^{+}$channels and $\mathrm{K}_{\mathrm{V}}$ channels (1.2 and 1.3 channels) (Feld et al., 2002; Suarez-Kurtz et al., 1999). In each case, channel inhibition occurs with similar potency in the low nanomolar range $(K d \sim 0.3$ and $10 \mathrm{nM})$ (Wallner et al., 1999). The concentration of charybdotoxin used in our study was sufficient to 
block $\mathrm{BK}_{\mathrm{Ca}}$ channels, but did not alter relaxation of the HIMA induced by resveratrol. Accordingly, it seems that charybdotoxin-sensitive channels are not involved in the mechanism of resveratrol-induced relaxation of the HIMA. This finding is in contrast to the finding of Wu et al. (2003) who demonstrated that resveratrol opens $\mathrm{BK}_{\mathrm{Ca}}$ channels in the vascular endothelial cell.

To analyze the contribution of $K_{V}$ channels to the resveratrol-induced relaxation in the HIMA, we used 4-AP. This compound is the most widely used blocker in the identification of potassium channel types. With very few exceptions, 4-AP have been shown to be without effect on $\mathrm{BK}_{\mathrm{Ca}}$ (Ritchie, 1987). Using low millimolar concentration, 4-AP achieved some selectivity for $K_{v}$ channels (Beech and Bolton, 1989). This feature complies with the results given by our experiments i.e. 4-AP (3 $\mathrm{mM})$ antagonized resveratrol-induced relaxation of HIMA rings with comparable potency. Thus, our finding supports a relevant participation of $K_{V}$ channels in the relaxation of HIMA produced by resveratrol. Consistent with this idea is the result obtained by Granados-Soto et al. (2002) that suggested that activation of $K_{V}$ channels participated in the peripheral nociceptive effect of resveratrol.

We used margatoxin in order to test which subtype of $K_{V}$ channels was included in resveratrol-induced relaxation of HIMA. This peptide is highly selective inhibitor of the $K_{v} 1$ channels, especially $1.1,1.2,1.3$, and 1.6 subtypes, but displays no affinity for the mammalian $\mathrm{BK}_{\mathrm{Ca}}$ channel (Garcia-Calvo et al., 1993, Cheong et al., 2001). $K_{v} 1.2$ and $K_{v} 1.3$ were identified in vascular smooth muscle cell of rat mesenteric artery; $\mathrm{K}_{\mathrm{V}} 1.1$ and $\mathrm{K}_{\mathrm{v}} 1.6$ were detected in smooth muscle cell of rat aorta and rat pulmonary artery but not in smooth muscle cell of mesenteric artery (Xu et al., 1999; Archer et al., 1998). This reflects tissue differences in expression of $K_{v} 1$ channels subtypes. In our study, th applied margatoxin (10 nM) was sufficient to block $K_{v} 1.1, K_{v} 1.2, K_{v} 1.3$, and $K_{v} 1.6$ channels, by abolishing resveratrol-induced relaxation, suggests that those channels might be included in the mechanism of resveratrol-induced endothelium-dependent vasodilatation of HIMA (Garcia-Calvo et al., 1993, Cheong et al., 2001). However, the fact that charybdotoxin, a potent blocker of $\mathrm{K}_{\mathrm{v}} 1.2$ and $\mathrm{K}_{\mathrm{v}} 1.3$ did not reproduce the effect of margatoxin suggests that $K_{v} 1.1$ and/or $K_{v} 1.6$ may be the relevant target. This observation needs further evaluation.

In conclusion, we have shown that resveratrol can induce relaxation of HIMA with endothelium. It seems that NO and 4-AP- and margatoxin-sensitive voltagegated $\mathrm{K}^{+}$channels located in the smooth muscle of HIMA are included in this relaxation. Further investigations have been necessary to explain the nature of interaction between $\mathrm{NO}$ and $\mathrm{K}^{+}$channels in HIMA.

\section{ACKNOWLEDGEMENT:}

We thank Mrs. Milena Zabunovic and Mr. Franjo Sostaric for technical support during this study. The study was supported by a Scientific Research Grant from Ministry of Science and Technology Serbia.

Address for correspondence:

Ass. Prof.: Dr. Ljiljana Gojković-Bukarica

Department of Clinical Pharmacology, Pharmacology and Toxicology,

School of Medicine, P.O.Box 840,

University of Belgrade, Belgrade 11129,

Serbia and Montenegro:

E-mail: bukarica@rcub.bg.ac.yu 


\section{REFERENCES}

1. Andriambeloson E, Stoclet JC, Andriantsitohaina R, 1999, Mechanism of endothelial nitric oxidedependent vasorelaxation induced by wine polyphenols in rat thoracic aorta, $J$ Cardiovasc Pharmacol, 33, 248-54.

2. Archer SL, Gragasin FS, Wu X, Wang S, McMurtry S, Kim DH, et al., 2003, Endothelium-derived hyperpolarizing factor in human internal mammary artery is 11,12 -epoxyeicosatrienoic acid and causes relaxation by activating smooth muscle BKCa channels, Circulation, 107, 769.

3. Archer SL, Souil E, Dinh-Xuan AT, Schremmer B, Mercier JC, Yagoubi EL, et al., 1998, Molecular identification of the role of voltage-gated $\mathrm{K}^{+}$channels, $\mathrm{K}_{\mathrm{V}} 15$ and $\mathrm{K}_{\mathrm{V}} 21$, in hypoxic pulmonary vasoconstriction and control of resting membrane potential in rat pulmonary artery myocytes, $J$ Clin Invest, 101, 2319-30.

4. Beech DJ, Bolton TB, 1989, Properties of the cromakalim induced potassium condutance in smooth muscle cells isolated from the rabbit portal vein, $\mathrm{Br} J$ Pharmacol, 98, 851-64.

5. Chen CK, Pace-Asciak CR, 1996, Vasorelaxing activity of resveratrol and quercetin in isolated rat aorta, Gen Pharmacol, 27, 363-6.

6. Cheong A, Dedman AM, Xu SZ, Beech DJ, 2001, Kv 1 channels in murine arterioles: differential cellular expression and regulation of diameter, Am J Physiol Heart Circ Physiol, 281, H1057$\mathrm{H} 1065$.

7. Cook NS, Quast U, 1990, Potassium channel pharmacology, In: Cook, NS, editor. Potassium channels: Structure, classification, function, and therapeutic potential, New York: John Wiley and Sons, 181-258.

8. Diebolt M, Bucher B, Andriantsitohaina R, 2001, Wine polyphenols decrease blood pressure, improve NO vasodilatation, and induce gene expression, Hypertens, 38, 159-165.

9. Feld Y, Melamed-Frank M, Kehat I, Tal D, Marom, Gepstein L, 2002, Electrophysiological modulation of cardiomyocytic tissue by transfected fibroblasts expressing potassium channels, Circulation, 105, 522-9.

10. Fitzpatrick DF, Hirschfield SL, Ricci T, Jantzen P, Coffey RG, 1995, Endothelium-dependent vasorelaxation caused by various plant extracts, J Cardiovasc Pharmacol, 26, 90-5.

11. Garcia-Calvo M, Leonard RJ, Novick J, Stevens SP, Schmalhofer W, Kaczorowski GJ, et al., 1993, Purification, characterization, and biosynthesis of margatoxin, a component of centruroides margaritatus venom that selectively inhibits voltage-dependent potassium channels, $J$ Biol Chem, 268, 18866-74.

12. Gewalting MT, Kojda G, 2002, Vasoprotection by nitric oxide: mechanisms and therapeutic potential. (Review), Cardiovasc Res, 55, 250-60.

13. Gojkovic-Bukarica Lj, Kazic T, Sajic Z, Djukanovic B, Panic, Peric M, 1997, The effects of levcromakalim and pinacidil on the human internal mammary artery, Fundam Clin Pharmacol, 11, 550-60.

15. Granados-Soto V, Arguelles CF, Ortiz MI, 2002, The peripheral antinociceptive effect of resveratrol is associated with activation of potassium channels, Neuropharmacology, 43, 917-23.

16. He GW, Yang CQ, Starr A, 1995, Overview of the nature of vasoconstriction in arterial grafts for coronary operations, Ann Thorac Surg, 59, 676-83.

17. Jager $U$, Nguyen-Duong $H, 1999$, Relaxant effect of trans-resveratrol on isolated porcine coronary arteries, Arzneim Forsch, 49, 207-11.

18. Kuriyama $H$, Kitamura $K$, Nabata $H$, 1995, Pharmacological and physiological significance of ion channels and factors that modulate them in vascular tissues, Pharmacol Rev, 47, 573-87.

19. Moncada S, Riggs A, Furchgott R, 1997, XIV International Union of Pharmacology. Nomenclature in nitric oxide research, Pharmacol Rev, 49, 137-42.

20. Naderali KE, Doyle JP, Williams G, 2000, Resveratrol induces vasorelaxation of mesenteric and uterine arteries from female guinea-pigs, Clin Sci, 98, 537-43.

21. Naderali KE, Smith LH, Doyle JP, Williams G, 2001, The mechanism of resveratrol-induced vasorelaxation differs in the mesenteric resistance arteries of lean and obese rats, Clin Sci,100, 55-60. 
22. Novakovic A, Gojkovic-Bukarica Lj, Cokic-Beleslin B, Zigon-Japundzic N, Sajic Z, Nezic D, et al., 2003, Differential antivasoconstrictor effects of levcromakalim and rilmakalim on the isolated human internal mammary artery and saphenous vein, J Pharmacol Sci, 92, 108-14.

23. Orallo F, Alvarez E, Camina M, Leiro J, Gomez E, Fernandez P, 2002, The possible implication of trans-resveratrol in the cardioprotective effects of long-term moderate wine consumption, $\mathrm{Mol}$ Pharmacol, 61, 294-302.

24. Ritchie AK, 1987, Two distinct calcium-activated potassium currents in a rat anterior pituitary cell line, J Physiol, 385, 591-609.

25. Rosenfeldt FL, He GW, Buxton BF, Angus JA, 1999, Pharmacology of coronary artery bypass grafts, Ann Thorac Surg, 67, 878-88.

26. Schmid-Antomarchi, H DeWelle J, Fosset M, Lazdunski M, 1987, The receptor for antidiabetic sulfonylureas controls the activity of the ATP-modulated $\mathrm{K}^{+}$channel in insulin-secreting cells, $J$ Biol Chem, 262, 15840-4.

27. Schoeffter P, Dion R, Godfraind T, 1988, Modulatory role of the vascular endothelium in the contractility of human isolated internal mammary artery, $\mathrm{Br} J$ Pharmacol, 95, 531-43.

28. Sturgess NC, Ashford ML, Cook DL, Hales CN, 1985, The sulfonylurea receptor may be an ATPsensitive potassium channel, Lancet, 2, 474-5.

29. Suarez-Kurtz G, Vianna-Jorge R, Pereira BF, Luisa Garcia M, Kaczorowski J, Peptidyl inhibitors of Shaker-Type $\mathrm{K}_{\mathrm{V}} 1$ channels elict twitches in guinea pig ileum by blocking $\mathrm{K}_{\mathrm{V}} 1.1$ at enteric nervous system and enhancing acetylcholine release, The $J$ Pharmacol Exp Ther, 289, 1517-22.

30. Wallner M, Meera P, Toro L, 1999,. Calcium-activated potassium channels in muscle and brain, In: Kurachi Y, Jan LY, Lazdunski M, editors, Current Topics in Membrane, Volume 46: Potassium ion channels, Molecular structure, function, and diseases, San Diego: Academic Press, 117-135.

31. Wu JM, Wang ZR, Hsieh, TC, Bruder JL, Zou JG, Huang YZ, 2001, Mechanism of cardioprotection by resveratrol, a phenolic antioxidant present in red wine (Review), Int J Mol Med, 8, 3-17.

32. $\mathrm{Wu} S N, 2003$, Large-conductance $\mathrm{Ca}^{2+}$-activated $\mathrm{K}^{+}$channels: physiological role and pharmacology, Curr Med Chem, 10, 649-61.

33. Xu C, Lu Y, Tang G, Wang R, 1999, Expression of voltage-dependent $\mathrm{K}^{+}$channel genes in mesenteric artery smooth muscle cells, Am J Gastrointest Liver Physiol, 277, G1055-G1063.

\section{ENDOTEL-ZAVISNA RELAKSACIJA UNUTRAŠNJE TORAKALNE ARTERIJE PROUZROKOVANA REZVERATROLOM} NOVAKOVIĆ ALEKSANDRA, GOJKOVIĆ-BUKARICA LJILJANA, PERIĆ M, NEŽIĆ D,
DJUKANOVIĆ B, LEŠIĆ A, BUMBAŠIREVIĆ M I MARKOVIĆ-LIPKOVSKI JASMINA

\section{SADRŽAJ}

Smatra se da rezveratrol kao jedna polifenolna komponenta prisutna u značajnim količinama u crnom vinu, smanjuje rizik od razvoja ateroskleroze i koronarne bolesti. U mehanizam kardioprotektivnog delovanja verovatno su uključeni antioksidativno, antitrombocitno i vazodilatatorno delovanje rezveratrola. Mehanizam vazodilatacije još uvek nije poznat, pa je cilj ovog rada bio da se ispitaju efekti i mehanizam vazorelaksantnog delovanja rezveratrola na humanoj unutrašnjoj torakalnoj arteriji sa endotelom. Unutrašnja torakalna arterija je prekontrahovana fenilefrinom. Rezveratrol je koncentracijski-zavisno relaksirao unutrašnju torakalnu arteriju čoveka. L-NAME, inhibitor NO sintaze, i metilensko plavo, inhibitor solubilne gvanilat ciklaze, su antagonizovali relaksaciju unutrašnje torakalne 
Acta Veterinaria (Beograd), Vol. 56. No. 2-3, 203-213, 2006

Novaković Aleksandra et al.: Endothelium-dependent relaxation

of internal mammary artery produced by resveratrol

arterije sa intaktnim endotelom, prouzrokovanu rezveratrolom. Visoko selektivni blokator ATP-senzitivnih $\mathrm{K}^{+}$kanala, glibenklamid, kao i neselektivni blokator velikih $\mathrm{Ca}$-senzitivnih $\mathrm{K}^{+}$kanala, karibdotoksin nisu antagonizovali rezveratrolom indukovanu relaksaciju unutrašnje torakalne arterije. 4-Aminopiridin i margatoksin, blokatori voltažnih $\mathrm{K}^{+}$kanala su antagonizovali relaksaciju prouzrokovanu rezveratrolom.

Na osnovu ovih činjenica se može zaključiti da je endotel-zavisna relaksacija unutrašnje torakalne arterije čoveka, prouzrokovana rezveratrolom, verovatno posredovana NO. Izgleda, da su 4-aminopiriin- i margatoksin-senzitivni K-kanali smešteni u membrani vaskularnih glatko-mišićnih ćelija humane unutrašnje torakalne arterije, uključeni u mehanizam endotel-zavisne relaksacije prouzrokovane rezveratrolom. 